\title{
Biodiversity of Invertebrates in Kemantren Coast, Lamongan
}

\author{
D A Rahayu* \\ Department of Biology, Faculty of \\ Mathematic and Natural Sciences \\ Surabaya, Indonesia \\ *dwirahayu@unesa.ac.id
}

\author{
R Ambarwati \\ Department of Biology, Faculty of \\ Mathematic and Natural Sciences \\ Surabaya, Indonesia \\ $\underline{\text { reniambarwati@unesa.ac.id }}$
}

\author{
U Faizah \\ Department of Biology, Faculty of \\ Mathematic and Natural Sciences \\ Surabaya, Indonesia \\ ulfifaizah@unesa.ac.id
}

\begin{abstract}
Kemantren beach is located in the Kemantren Village, Paciran District, Lamongan Regency. This beach is consists of sand and coral substrate. Kemantren beach is one of the small coastal islands of Java that has already reclaimed with spot of high ecotourism potency and habitat for numerous types of invertebrate. Unfortunately, there were no previous records about invertebrate biodiversity in this area. The purpose of this research was to identify various invertebrate species inhabiting Kemantren beach, Lamongan by describing their morphological characteristics and habitat. Specimens were collected from intertidal and shallow subtidal zone using sweeping techniques along the coastal line. Morphological and habitat data were analysed descriptively. Results showed that there were seven invertebrates phyla inhabited Kemantren coastal water; Mollusca, Annelida, Porifera, Arthropoda, Echinodermata, Coelenterata, and Platyhelminthes. We had identified a total of 19 bivalves and 33 gastropods species distributed among 20 families. Invertebrate biodiversity in Kemantren coastal consisted of 100 species belonged to 79 genera, 45 families and 9 classes (Gastropoda, Bivalvia, Polychaeta, Demospongiae, Crustacea, Holothuroidea, Ophiuroidea, Anthozoa and Turbelaria). Identification of invertebrates is useful tool for biodiversity, management, conservation and development of science. We recommend exploring potential of these species as source of sustainable income for the locals.
\end{abstract}

Keywords - biodiversity, invertebrate, morfological, habitat

\section{INTRODUCTION}

Invertebrates composed $95 \%$ of all animal species that have been identified. They have the most abundant distribution with unique niche in each ecosystem [2] Invertebrates are divided into several phyla; Arthropoda, Mollusca, Echinodermata, Annelida, Porifera, Coelenterata, Nemathelminthes, and Platyhelminthes [1]. In Indonesia, there are approximately 1,800 species that belong to invertebrate phylum [3]. Ministry of Environment and Forestry of Indonesia [4] recorded that invertebrates found in Indonesia were included: 1,400 species of Brachyura from Crustacean group, 1,500 gastropod (oyster/snail) and 100 bivalve species (clamp) from molluscs group, 91 crinoid (sea lilies), 87 asteroid (sea star), and 142 holothurian (sea cucumber) species of Echinodermata group, 830 species of sponges (demospongia), and 70 species of bristle worms (Polychaeta) mostly from Terebellidae family.

Marine coastal water is a substantial habitat for many types of invertebrates. It is mainly characterized by intertidal zone, which has dynamic fluctuating physical circumstances [5], This zone, even if it is sometimes very narrow, is inhibited by various forms of marine life easily observed [6], Thus, this zone has become popular place to study invertebrate community, in relation to their natural habitat [7] [8] or anthropogenic factors [9] [10]. Record of invertebrate diversity in Indonesian marine coastal was still fairly low. Istaqlal et al. [11] had previously identified 19 species belonged to 9 classes of invertebrate phyla at Nyangnyang Beach, while 10 species belonged to 4 classes were only found at Merta Segara Beach, Bali. Baderan et al [12] found 14 families of molluscs comprised of 11 gastropod families (21 species) and bivalve families (3 species) in mangrove ecosystem coastal of North Sulawesi, Indonesia, while Alwi et al [13] recorded invertebrates in Morotai regency, found that dominance index at all three stations studied was low with domination of Linckia laevigata, Tridacna derasa, and Tridacna squamosal.

Kemantren is a small coastal island located in the northeastern shore of Java. Invertebrate animals are one of the common components of Kemantren coastal ecosystems, found mostly in the intertidal zone. Kemantren coast is located in the Kemantren Village, Paciran District, Lamongan Regency, mainly consisted of sand and coral substrate. Kemantren coast is located geographically at coordinate $6^{\circ} 51^{\prime} 54^{\prime \prime}$ to $7^{\circ} 23^{\prime \prime} 6^{\prime \prime} \mathrm{S}$ and $122^{\circ} 4^{\prime \prime} 4^{\prime \prime}$ to $122^{\circ} 33^{\prime \prime} 12^{\prime \prime} \mathrm{E}$. In addition, the island is directly bordered by Java Sea in the north, Gresik Regency in the East, Mojokerto Regency and Jombang Regency in the South, and Bojonegoro and Tuban Regencies in the West. The shoreline of this beach is characterized as rocky and coral reefs.

Lamongan regency has an area of approximately $1,812.8$ $\mathrm{km}^{2}$ with $47 \mathrm{~km}$ of coastline length. The total area of waters is $902.4 \mathrm{~km}^{2}$, calculated 12 miles from the coast. Kemantren beach is one of the coastal islands of Java already reclaimed. This area has potency as ecotourism spot and habitat of invertebrate biodiversity. Furthermore, topographic features of Kemantren coastal contribute to the relatively high abundant distribution of marine invertebrates. Invertebrate biodiversity was expected to be dynamic and abundant in Kemantren beach. No study to date had reported invertebrate biodiversity of this location in detail.

The purpose of this study was to identify invertebrate species inhabiting Kemantren beach, Lamongan by describing their morphological characteristics and habitat. Identification of invertebrate species is a useful tool for biodiversity, management, conservation, and development of science. Identification of invertebrates is useful tool for 
biodiversity, management, conservation and development of science.

\section{METHOD}

\subsection{Marine Invertebrate Sampling}

This research was performed on March-May 2019 in Kemantren coast, Lamongan, Indonesia. Three spots in intertidal zone hypothesized to be inhabited by invertebrates were determined (lower intertidal, middle intertidal and upper intertidal). Lower intertidal area is a rocky beach area; middle intertidal is rocky beach with a few sandy areas, while the upper zone is a rocky and sandy beach area. In the three spots, the $1 \times 1 \mathrm{~m}$ plot was made replicated twice. All specimens were collected from intertidal and shallow subtidal zone by sweeping techniques along the coastal line. The methods used explorative survey method.

\subsection{Description, Identification and Classification}

All sample collected was fixed in $70 \%$ alcohol in the field and transferred to laboratory for further processing. Samples were observed of their morphological characteristics and sorted into major fauna groups. After sorted, samples were rinsed with distilled water and preserved in $70 \%$ ethanol. They were further identified up to species level under stereomicroscope and light microscope.

Identification techniques and description of invertebrates were based on macroscopic morphological characteristics, including body shape/colony, body-color, body size, and diagnostic characters. Especially in sponge, additional diagnostic characters of anatomical (ostia and osculate) features were observed microscopically on small pieces of sponge sample. Spicules identification was conducted by soaking large pieces of sponge in Clorox solution added with a few $\mathrm{ml}$ of $70 \%$ alcohol for 2-3 days sludge was submerged. Sludge was then taken with a clean small brush and observed using microscope. The primary data were generated by identifying all invertebrate species, i.e. Gastropoda, Bivalvia, Polychaeta, Demospongiae, Crustacea, Holothuroidea, Ophiuroidea, Anthozoa and Turbelaria.

Invertebrates attached on rocks of the intertidal zone were collected using a chisel and a pair of tweezers. Specimens were collected in accord to the respective taxon, fixed in $70 \%$ ethyl alcohol or $5 \sim 10 \%$ formalin on the spot. Species were investigated in Systematic Laboratory, Department of Biology, Universitas Negeri Surabaya. Specimens were identified based on morphological characteristics. All of the invertebrate classification was referred to World Register of Marine Species-WoRMS (http://www.marinespecies.org/) [14-20], crustacean was identified based on Biodiversity Warriors and Atlas of Living Australia; coral identification used Types of Coral Types in Indonesia (LIPI), sponge was identified based on Systema Porifera: A Guide to the Classification of Sponges (John Hooper and Robert van Soest, 2002) [21] along with database of world sponges found at marinespecies.org/porifera, bivalve identification was based on Bivalves of Australia Volume 2 [22] and The Living Marine Resources of The Western Central Pacific Volume 1
[23,24] ; while sea anemone identification was based on Wild (http://www.wildsingapore.com/wildfacts/cnidaria) and Animal Diversity Web (https://animaldiversity.org.accounts/Anthozoa).

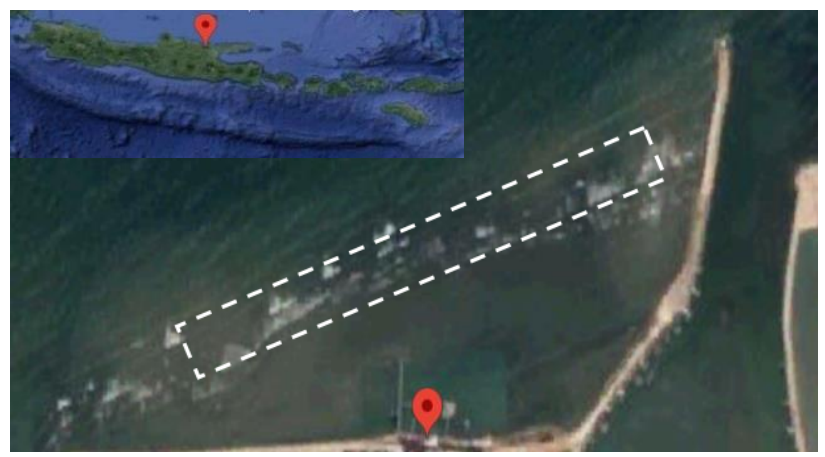

Fig. 1. Sampling location along Kemantren Coast, Lamongan, Indonesia (Google Earth)

\subsection{Environmental factors}

Parameters measured during the sample collections were $\mathrm{pH}$ and temperature. The measurement of habitat parameters is measured at three different stations, i.e. station I, station II and station III. Temperature measurement using a thermometer and $\mathrm{pH}$ measurement using a $\mathrm{pH}$ meter.

\section{RESULTS AND DISCUSSION}

\subsection{List of Species}

Species identified in the current study was numbered 100 species, belonged to 79 genera, 45 family, and 9 classes (Gastropoda, Bivalvia, Polychaeta, Demospongiae, Crustacea, Holothuroidea, Ophiuroidea, Anthozoa and Turbelaria). This study identified 33 species of Gastropod (33\%), 19 species of Bivalve (19\%), 3 species of Polychaeta (3\%), 3 species of Demospongia (7\%), 14 species of Crustacea (14\%), 3 species Holothuroidea (3\%), 1 species of Ophiutoidea (1\%), 16 species of Anthozoa (16\%), and 4 species of Turbelaria (4\%). Diversity of mollusc species was the highest in Kemantren (Figure 3). The least number of invertebrate species was Ophiactis savignyi of Ophiutoidea. No previous data was recorded related to invertebrates found at Kemantren. As a small coastal area, Kemantren has a relatively high taxonomic richness of marine invertebrates (Table 1.). The study conducted in depth investigation on Kemantren coastal which is expected 7 phyla, i.e. Molluscs, Echinodermata, Cnidaria, Annelida, Porifera, and Platyhelminthes diversity.

\subsection{Morphology of commonly found species}

\section{Porifera}

Seven species from 7 families of Demospongiae class were found in Kemantren Coast. The most abundant species from this phylum was Euspongia officinalis, which has characteristics of large-sized and bright-colored with intricate channels ended in small, round holes. Spicules have consisted of silicates, sponge collagen fibers or speculators are absent. Skeletal is composed of spongin and Diea-Oxea type microspheres and Diactinal strongyle megaslera. 
TABLE I.

INVERTEBRATE SPECIES FOUND IN KEMANTREN COAST

\begin{tabular}{|c|c|c|c|c|}
\hline Phylum & Class & Family & Genus & Species \\
\hline \multirow[t]{42}{*}{ Mollusc } & \multirow[t]{33}{*}{ Gastropoda } & Chromodorididae & Chromodoris & Chromodoris lineolata \\
\hline & & \multirow[t]{5}{*}{ Cirridae } & \multirow[t]{4}{*}{ Tectus } & Tectus fenestratus \\
\hline & & & & Tectus pyramis \\
\hline & & & & Tectus fenestratus \\
\hline & & & & Tectus pyramis \\
\hline & & & Clanculus & Clanculus artopurpureus \\
\hline & & \multirow[t]{2}{*}{ Turbinidae } & Astralum & Astralum calcar \\
\hline & & & Turbo & Turbo bruneus \\
\hline & & Patellidae & Patella & Patella caerulea \\
\hline & & \multirow[t]{3}{*}{ Buccinidae } & \multirow[t]{2}{*}{ Engina } & Engina alveolata \\
\hline & & & & Engina zonalis \\
\hline & & & Pyrena & Pyrena fasciata \\
\hline & & \multirow[t]{5}{*}{ Cerithiidae } & \multirow[t]{3}{*}{ Cerithium } & Cerithium alveolum \\
\hline & & & & Cerithium coralum \\
\hline & & & & Cerithium tenellum \\
\hline & & & Clypeomorus & Clypeomorus coralium \\
\hline & & & Rhinoclavis & Rhinoclavis articulata \\
\hline & & \multirow[t]{2}{*}{ Cirridae } & Clanculus & Clanculus atropurpureus \\
\hline & & & Trochus & Trochus maculatus \\
\hline & & Conidae & Tomopleura & Tomopleura pauloensis \\
\hline & & \multirow[t]{3}{*}{ Cypraeaidae } & \multirow[t]{2}{*}{ Cypraea } & Cypraea caurica caurica \\
\hline & & & & Cypraea pallida \\
\hline & & & Erronea & Erronea ovum \\
\hline & & \multirow[t]{3}{*}{ Muricidae } & Drupella & Drupella margariticola \\
\hline & & & Morula & Morula granulata \\
\hline & & & Thais & Thais asmigera \\
\hline & & \multirow[t]{3}{*}{ Turbinidae } & Astrea & Astrea calcar \\
\hline & & & \multirow[t]{2}{*}{ Turbo } & Turbo bruneus \\
\hline & & & & Turbo petholatus \\
\hline & & Vasidae & Vasum & Vasum turbinellum \\
\hline & & \multirow[t]{2}{*}{ Muriidae } & Drupella & Drupella margariticola \\
\hline & & & Morula & Morula Granulata \\
\hline & & Pteriidae & Pinctada & Pinctada maculata \\
\hline & \multirow[t]{9}{*}{ Bivalvia } & Cardidae & Bucardium & Bucardium asiaticum \\
\hline & & \multirow[t]{8}{*}{ Veneridae } & Circe & Circe scripta \\
\hline & & & \multirow[t]{3}{*}{ Dosinia } & Dosinia contusa \\
\hline & & & & Dosinia derupta \\
\hline & & & & Dosinia fibula \\
\hline & & & Fimbria & Fimbria sowerbyi \\
\hline & & & \multirow[t]{2}{*}{ Gafrarium } & Gafrarium dispar \\
\hline & & & & Gafrarium divaricatum \\
\hline & & & Glycymeris & Glycymeris reevei \\
\hline
\end{tabular}




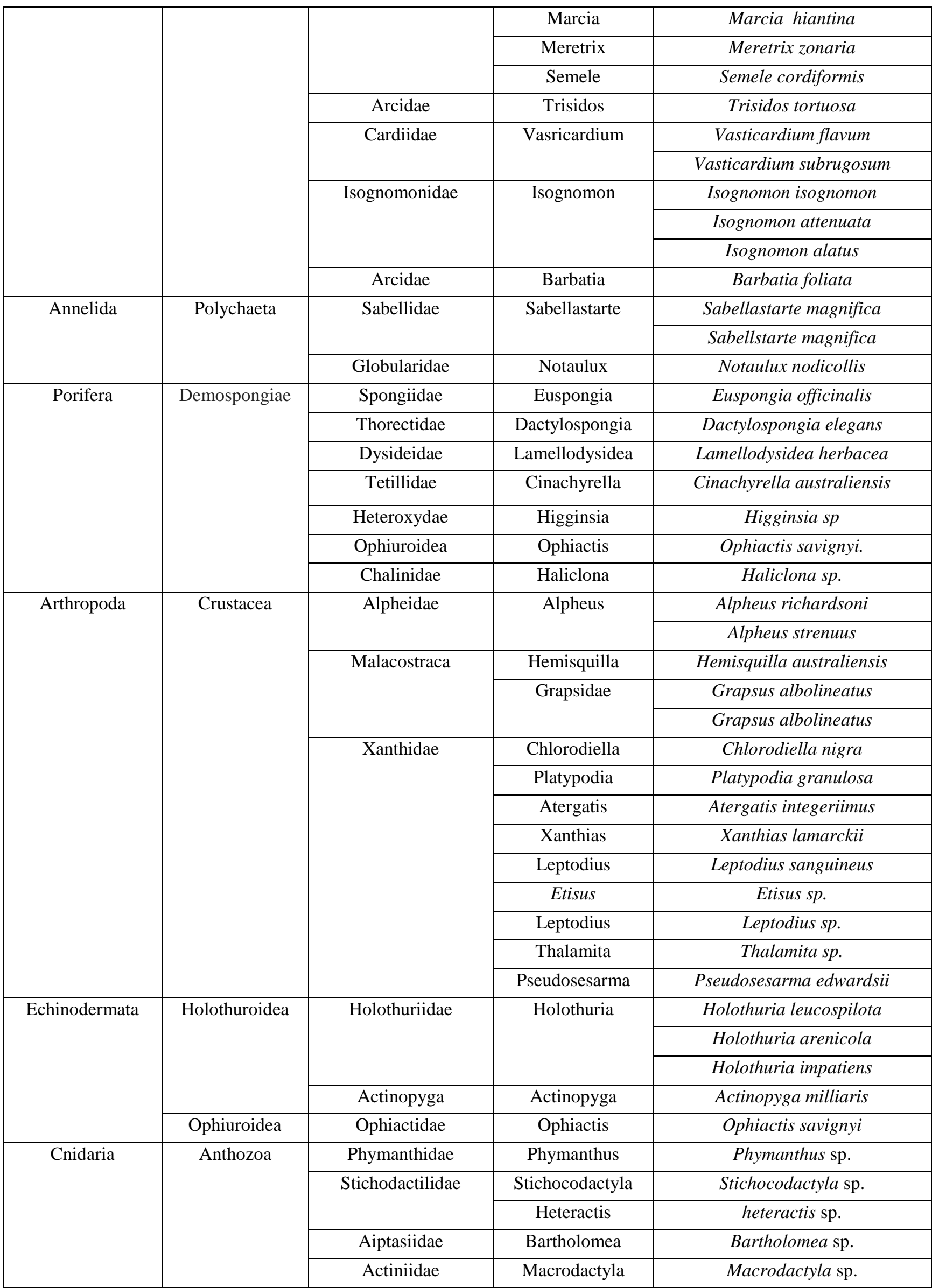




\begin{tabular}{|c|c|c|c|c|}
\hline & & & Actinia & Actinia sp. \\
\hline & & & Entacmaea & Entacmaea sp. \\
\hline & & Asteroidea & Patiria & Patiria miniata \\
\hline & & & Anthenea & Anthenea aspera \\
\hline & & Euphylliidae & Galaxea & Galaxea astreata \\
\hline & & Acroporidae & Acropora & Acropora granulose \\
\hline & & & Montipora & Montipora tuberculosa \\
\hline & & Agariciideae & Coeloseris & Coeloseris mayeri \\
\hline & & & Gardineroseris & Gardineroseris planulata \\
\hline & & Fungiidae & Cycloseris & Cycloseris costulata \\
\hline & & Merulinidae & Hydnophora & Hydnophora pilosa \\
\hline Platyhelminthes & Turbelaria & Pseudocerotidae & Thysanozoon & Thysanozoon nigropapillosum \\
\hline & & & Pseudoceros & Pseudoceros concinnus \\
\hline & & & & Pseudoceros tristriatus \\
\hline & & & & Pseudoceros indicus \\
\hline
\end{tabular}

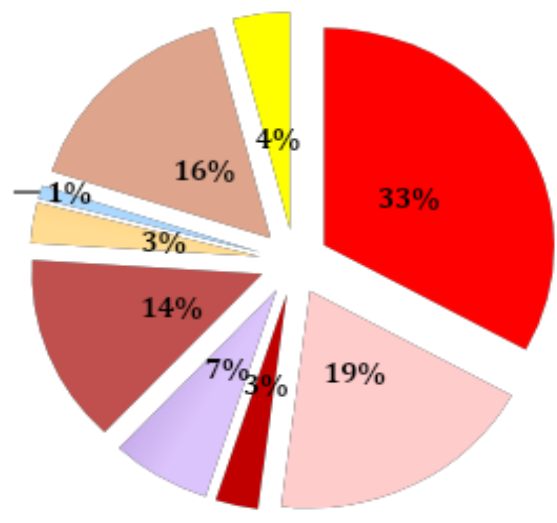

Gastropoda

$\square$ Bivalvia

- Polychaeta

Demospongiae

Crustacea

$\square$ Holothuroidea

Ophiuroidea

Anthozoa

$\square$ Turbelaria

Fig. 2. Percentage of species abundance of respective class inhabited Kemantren coast

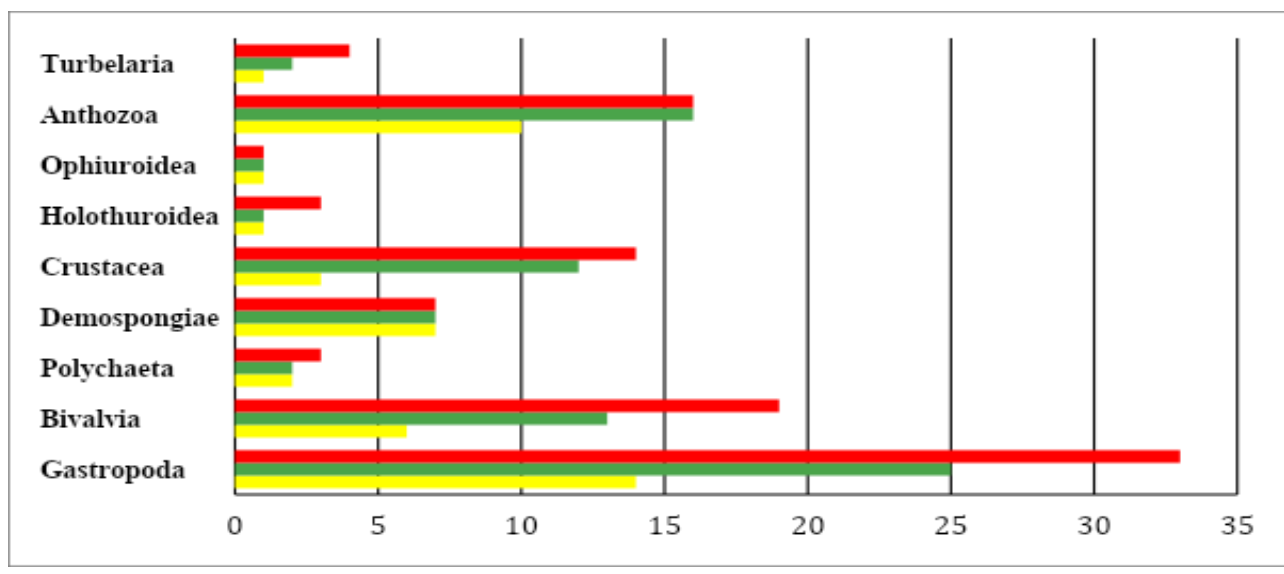

Fig. 3. Diversity of invertebrate found in Kemantren Coast

\section{Platyhelminthes}

Three species of Turbelaria belonged to Planoceridae family was first recorded from Kemantren coastal in the current study. The species can be differentiated based on the color on dorsal and ventral body surface and a number of stripes found on dorsal body surface. Pseudoceros concinnus was abundant, characterized by 1 orange stripe on the dorsal; Pseudoceros tristriatus have 3 orange strips on dorsal surface, while Pseudoceros indicus have no strip. 
Thysanozoon nigropapillosum was not abundant in this coast.

\section{Cnidaria}

Anthozoa class is considered as the largest class of cnidarians, well-known as flower-like animals, such as sea pen, sea anemone, and coral. Sixteen species from 16 genus (Phymanthus, Stichocodactyla, Heteractis, Bartholomea, Macrodactyla, Actinia, Entacmaea, Patiria, Anthenea, Galaxea, Acropora, Montipora, Coeloseris, Gardineroseris, Cycloseris, and Hydnophora) and 10 families of Anthozoa class were recorded during the study. The most abundant Cnidarian phyla found was coral, consisted of 5 families and 7 species that were found to undergone bleaching. Six species found were Galaxea astreata with submassive lifeform and phaceloid coralit, Acropora granulose with branches and dendroit coralit, Coeloseris mayeri with tabulate and Hydnoporoid, Cycloseris costulata with mushroom form and solitary coralit, Gardineroseris planulata with massive lifeform. The species found in the least number was Hydnophora Pilosa, which can be differentiated based on lifeform and coralit type.

The skeleton of Galaxea is very distinctive. Corallites are extremely plocoid, though in this species they are usually smaller. The $2-10 \mathrm{~mm}$ tall cylinders are $3-5 \mathrm{~mm}$ in diameter and are set into a flat and rather blistery coenosteum. The corallites are well spaced. There are 8-12 protuberant primary septa, projecting a further $2-3 \mathrm{~mm}$ above the corallite wall [14]; Coeloseris mayeri, Colonies are massive either rounded or hillocky. Corallines are cerioid, without columellae and with Pavona-like septocostae. Polyps are extended only at night [16]; while the characteristics of Gardineroseris planulata were colonies are massive, reaching $1 \mathrm{~m}$ across. Calices are polygonal, not round, and $3-5 \mathrm{~mm}$ in diameter. The inside walls appear to the naked eye to be smoothly concave surfaces because the septa are very numerous, close together and of uniform height. Tall corallite walls may surround a single or a dividing group of corallites [21].

\section{Echinodermata}

Five species from three families of Echinodermata were found in Kemantren coast. Based on observation, 32 sea cucumbers were collected and identified. The most abundant species were found in the rock and sandy ecosystem; Holothuria impatiens, $H$. arenicola, $H$. leucospilota, and Actinopyga milliaris. The Holothuriidae family has round body section. The most striking difference of the three genera can be seen from the anal region. Holothuria has round or flattened bodies on the ventral side of body and round anal holes. The colour of body was yellow beneath with orange apexes papillae covering the surface.

\section{Arthropoda}

Fourtheen species belonged to three family (Alpheidae, Malacostraca, and Xanthidae) was first recorded from Kemantren coastal in the current study. The most abundant of Alpheidae family were Alpheus richardsoni and Alpheus strenuus with almost the same variation in morphological forms. Alpheus spp. has the characteristics of large claws and small claws, Alpheus richardsoni has large grayish gray claws with white gradations, thinner claws and pointing to the tip, while Alpheus Strenuus has a large greyish brown with white gradations. The most abundant species of Malacostraca family was Thalamita sp. with following characteristics has a Hexagonal body shape, long flat tapered shape, flat carapace shape, a pair of swimming legs with flat end, 3 foot pairs with smooth and sharp point, the colour orange in the legs, greenish in the carapace, and bone white in the ventral.

\section{Annelida}

Three species of Polychaeta belonged to Sabellidae and globularidae family was first recorded from Kemantren coastal in the current study. The most abundant species were found in the lower intertidal zone; Sabellstarte magnifica with diagnostic characteristics were the crown is coloured in shades of brown with several series of spots forming bands of brown with light spots, the colouring of the pattern is brown, the tube where the rest of the animal resides is parchment-like, and often hidden in recesses or embedded in the coral; radiola was found in branching tentacles; brownish red crown; and the crown size in $7 \mathrm{~cm}$.

\section{Molluscs}

Diversity of mollusc species was the highest in Kemantren coast. Three species belonged to Cirridae family were abundant in Kemantren coastal, i.e. Tectus fenestratus, Clanculus artopurpureus, and Tectus pyramis. The animal is spread over the upper, lower and middle intertidal zone. The three members of the Cirridae family have almost the same morphological characteristics including medium to large shell sizes, have cone shells, the direction of dextral shell rotation/ right round, consisting of 3-5 threads, round shell shape, and round eggshell shape. Tectus fenestratus and Tectus pyramis have been found in the coral reefs of Bacan Island, North Maluku with the presence of $13 \%$ and $47 \%$ [25]. In the bottom intertidal zone, it was found Nurdibranchia, i.e. Chromodoris lineolata, Characteristically there is a black line adjacent to the inner edge of the orange border, the diagnostic character with a pattern of multiple longitudinal stripes of black or dark brown and white on the mantle.

\subsection{Environmental factor in the research site}

The environment factor is crucial in supporting the growth of invertebrate, thus environment becomes an important part of any biological study. Parameters measured during the sample collections were $\mathrm{pH}$ and temperature. Water temperature at Kemantren coast ranged from $28-29^{\circ} \mathrm{C}$ during the duration of the study, which was good to support the life of invertebrates. Water temperature tolerance of most invertebrate is ranged $26-30^{\circ} \mathrm{C}$ [27]. This was also emphasized by Hicks and McMohan [28] who elaborated that general optimum temperature for Molluscs is $15-28^{\circ} \mathrm{C}$. Furthermore, optimum temperature for Bivalvia was at 20$30^{\circ} \mathrm{C}$, while Gastropod was $25-32^{\circ} \mathrm{C}$ [29]. Temperature above $32^{\circ} \mathrm{C}$ causes a metabolic process to be disrupted. Change of temperature beyond optimum limit will affect not only growth, but also reproduction of the organism.

Water quality was considered good, with $\mathrm{pH}$ recorded tended to be alkaline (>7). The acidity of water is mostly 
affected by biological activity; photosynthesis, temperature, and oxygen content [30] among other aquatic factors. Changes in $\mathrm{pH}$ induce imbalance of carbon dioxide, bicarbonate, and carbonate level in the water. Productive and ideal waters for marine life have $\mathrm{pH}$ ranged at 6.6 to 8.5 [31]. Measured $\mathrm{pH}$ at Kemantren Coast was classified as good for survival of marine invertebrates.

The Kemantren marine invertebrate still needs more investigation and further research, especially on the biodiversity of them. Difficulty in accessing the coast was the prime reason limiting in-depth invertebrate studies of invertebrate biodiversity at this location. Further study of marine invertebrate on their molecular and population genetic will benefit conservation and biodiversity concerns in this coastal area.

\section{CONCLUSION}

In the current study, diversity of invertebrates in Kemantren coast was identified to be consisted of 100 species, belonged to 79 genera, 45 families and 9 classes (Gastropoda, Bivalvia, Polychaeta, Demospongiae, Crustacea, Holothuroidea, Ophisuroidea, Anthozoa and Turbelaria).

\section{REFERENCES}

[1] R.D. Barnes, "Invertebrate zoology (No. Ed. 5),'WB Saunders company, 1987.

[2] P. Puranik \& Bhate, 'A. Animal Forms and Functions: Invertebrate,' Sarup \& Sons, 2007

[3] M. Hutomo, M.K. Moosa, "'Indonesian Marine and Coastal Biodiversity: Present status," Indian J. Mar. Sci., vol. 34, pp.88-97, 2005.

[4] Ministry of Environment and Forestry of Indonesia, 'The Fifth National Report of Indonesia to The Convention on Biology Diversity Deputy Minister of Environmental Degradation Control and Climate Change,', 2014

[5] J.W. Nybakken, ''Ekologi Laut Suatu Pendekatan Ekologi,' Jakarta: PT. Gramedia, 1988.

[6] J.W. Nybakken, S.K. Webster, 'Life In The Ocean, in The Ocean, Scientific American, pp. 74-87, 1988

[7] N.J. De Voogd, L.E. Becking, and D.F.Cleary, 'Sponge Community Compositon In The Derawan Island, NE Kalimantan,', Indonesia Marine Ecology Progress Series, vol. 396, pp.169-180, 2009.

[8] K.L. White, S.M. Townsend, A.S. Reynolds, and E.B.Barrington, "Intertidal Invertebrates in Scaterie Island: A Preliminary Species Inventory And Habitat Description Proceedings of Nova Scotian Institute of Science, 2010.

[9] R.C. Presscot, "An Investigation into The Impacts of Recreational Activities of Intertidal Assemblages at Westward Ho,' Devon Earth \& E-nvironment, vol. 2, pp. 211-252, 2006.

[10] M.N. Ferreira and S. Rosso, "Effect Of Human Trampling On Rocky Shore Fauna On The Sao Paulo Fauna," Southeasthern Brazil Brazillian J. Biol., vol. 6, pp. 993-999, 2009.

[11] B.A. Istaqlal, I.W. Kasa, and D.S. Yusup, 'Invertebrates Diversity of Merta Segara and Nyangnyang Beach: Comparison Study of Two Beaches with Different Characteristics," J. Advances in Tropical Biodivers. and Environmental Sciences, vol. 2, pp. 14-21, 2018.

[12] D.W.Baderan, M.S. Hamidun, R. Utina, S. Rahim, and R. Dali, 'The abundance and diversity of Mollusks in mangrove ecosystem at coasta area of North Sulawesi,' Indonesia, Biodiversitas, vol. 20, pp.987993, 2019

[13] D. Alwi, S.H. Muhhamad, and S. Bisi, 'Inventarisasi organisme avertebrata terumbu karang di perairan Tanjung Dehegila Kabupaten Pulau Morotai,', J. Ilmu Kelaut. Kepul., vol.1, pp.71 - 83, 2018.

[14] B.W. Hoeksema, and S. Cairns, 'World List of Scleractinia. Galaxea astreata (Lamarck, 1816) accessed through: World Register of Marine Species," at:http://www.marinespecies.org/aphia.php?p=taxdetails\&id=2073, vol. 68, pp. 08-22, 2019.

[15] R.W.M. Van Soest, N. Boury-Esnault, J.N.A. Hooper, K. Rützler, N.J. de Voogd, B. Alvarez, E. Hajdu, A.B. Pisera, R. Manconi, C. Schönberg, M. Klautau, B. Picton, M. Kelly, J. Vacelet, M. Dohrmann, M.C. Díaz, P. Cárdenas, J.L. Carballo, P. Ríos, R Downey, 'World Porifera Database. Euspongia officinalis (Linnaeus, 1759). Accessed through: World Register of Marine Species at:http://www.marinespecies.org/aphia.php? $\mathrm{p}=$ taxdetails\&id=1947, on 12-08-2019.

[16]B. W. Hokeima, S. Cairns, "2019 World List of Scleractinia. Coeloseris mayeri Vaughan," 1918. Accessed through: World Register of Marine Species at:http://www.marinespecies.org/aphia.php?p=taxdetails\&id=207613 on $22^{\text {th }}$ August 2019.

[17]B. W. Hokeima, S. Cairns, 2019 World List of Scleractinia. Gardineroseris planulata (Dana, 1846). Accessed through: World Register of Marine Species at:http://www.marinespecies.org/aphia.php?p=taxdetails\&id=207274 on $22^{\text {th }}$ August 2019.

[18]WoRMS, 'Holothuria (Thymiosycia) impatiens (Forsskål, 1775), "Accessed http://www.marinespecies.org/aphia.php?p=taxdetails\&id=125185 on $22^{\text {th }}$ August 2019

[19]B.W. Hoeksema, S. Cairns, 'World List of Scleractinia. Cycloseris costulata (Ortmann, 1889) Accessed through: World Register of Marine Species", at:http://www.marinespecies.org/aphia.php?p=taxdetails\&id=207325 on $22^{\text {th }}$ August 2019.

[20] R. W. Van Soest, N. Boury-Esnault, J.N.A. Hooper, K. Rützler, N.J. de Voogd, B. Alvarez, E. Hajdu, A.B. Pisera, R Manconi, C Schönberg, M. Klautau, B. Picton, M. Kelly, J. Vacelet, M. Dohrmann, M.C. Díaz, P. Cárdenas, J.L. Carballo, P. Ríos, R. Downey, 'World Porifera Database. Lamellodysidea herbacea (Keller, 1889) accessed through: World Register of Marine Species"' at: http://www.marinespecies.org/aphia.php? $\mathrm{p}=$ taxdetails\&id $=164988$ on $22^{\text {th }}$ August 2019

[21]B.W. Hoeksema, S. Cairns, S, "World List of Scleractinia. Gardineroseris planulata (Dana, 1846) Accessed through: World Register of Marine Species" at: http://www.marinespecies.org/aphia.php? $\mathrm{p}=$ taxdetails\&id $=207274$ on $22^{\text {th }}$ August 2019.

[22]J.N. Hooper and R.W. Van Soest, "Systema Porifera A Guide to the Classification of Sponges,' Springer, 2002.

[23]K. Lamprell, and H. John, 'Bivalves of Australia Volume 2. Leiden:Backhuys Publishers, 1998.

[24]E. K. Carpenter, and H. N. Volker,' The Living Marine Resources of the Western Central Pacific Volume 1. Rome: Food and Agriculture Organization of the United Nations, 1998.

[25]B. Dharma, E. Schwabe, S. Schrodl, 'Recent and Fossil Indonesian Shells University of California', USA, 2006.

[26]H.A.W. Cappenberg, "Inventarisasi dan Sebaran Moluska di Terumbu Karang Perairan Pulau Bacan, Provinsi Maluku Utara,’ J. Ilmu Teknol. Kelaut. Tropis, vol. 9, pp. 269-270, 2017.

[27]G. J. Bakus, 'A comparison of some population density sampling technique for biodiversity, conservation, environmental impact studies," J. Biodiversity Concerv., vol. 16, pp. 2445-2455, 2007.

[28]D.W. Hicks and R.F. McMohan, "'Temperature Acclimation of upper and lower thermal limits and freeze resistance in the nonindigenous brown mussel, Perna perna (L) from Gulf of Mexico', Mar. Biol., vol. 140, pp.1167-1179, 2017.

[29] M.I. Masrur, 'The spatial distribution of gastropods and their relation to environmental characteristics in the coastal of Nusalaut, Maluku Tengah', J. Ilmu Teknol. Kelaut. Tropis, vol. 7, pp.365-378, 2007.

[30]M. Sukmiwati, 'Keanekaragaman Teripang (Holothuroidea) di Perairan Bagian Timur Pantai Natuna Kepulauan Riau,“ J. Nat. Indonesia, vol.14, pp.131-137, 2017.

[31] J. Dafni, 'Diversity and recent change in the echinoderm fauna of the Gulf of Aqaba with Emphasis on the regular Echinoids In: F.D POR (ed)Aqaba-Eliat, the Improbable Gulf: Enviroment, Biodiversity and Preservation Magnes Press Jerussalem,'’ 2008. 